\title{
Professional Development In Monitoring And Evaluation And Result Utilization In Meru Region In Kenya
}

\author{
Dr. Kithinji Cavens, PhD \\ Pan Africa Christian University; Kenya \\ Prof. Harriet Kidombo
}

Senior Lecturer Department of Extra Mural Studies, University of Nairobi

Prof. Christopher Gakuu

Senior Lecturer Department of Educational Studies, University of Nairobi

doi: 10.19044/esj.2016.v12n23p309 URL:http://dx.doi.org/10.19044/esj.2016.v12n23p309

\begin{abstract}
This study was carried out to determine the influence of professional development in Monitoring and result utilization in Meru Region; Kenya. Pragmatic approach was used to lay foundation for a mixed mode approach in methodology thus allowing for both descriptive and inferential analysis of data. The study targeted employees working in project organizations in the region and had an experience of over two years. The sample size was 218. In general, the study noted high level of M\&E results utilization at project level by project employees and that Professional development activities were being carried in the region at moderate extent. Together, all activities carried out to develop professionalism in M\&E had a positive high correlation thus concluding that they have influence on the actual utilization of M\&E result. The study established that a unit increase in professional development in the region result to $43.6 \%$ increase in $\mathrm{M} \& \mathrm{E}$ result utilization. It was recommended that more of professional development activities in M\&E be undertaken to include even other users of M\&E result outside the Project organization to maximize on the evaluation results in order to justify the resources used in carrying M\&E in organizations
\end{abstract}

Keyword; Evaluation Capacity Building (ECB), professional development in $M \& E$, training in $M \& E$, technical assistance, collaborative $M \& E, M \& E$ community of practice, M\&E mentoring and coaching programs

\section{Introduction}

The objective of any monitoring and evaluation ystem should never be to produce large volumes of performance data, or a large number of high- 
quality evaluations but to produce information that is usable in a number of ways. This is to say that M\&E system should not be supply-driven but demand-driven if we have to see its usefulness (Woodhill, 2005). Besides that, evaluations are a costly venture and there is need for justification of this cost. The one all time justification of the cost of M\&E is usability of its results (Patton, 1999). Patton noted that the value of an evaluation has to at least equal its cost and should be evaluated according to its utilization and that $M \& E$ result utilization is not something one becomes interested in at the end of an evaluation but rather it should be integrated from the moment stakeholders and evaluators begin interacting and conceptualizing the evaluation decisions, since these decisions would affect utilization in a major way. This calls then for development of professionalism in M\&E.

Utilization of $M \& E$ result has been cited as wanting in a number of studies. Segone (2008) cited the World Bank Independent Evaluation Group conclusion that, for all development agencies funded by World Bank, monitoring and evaluation remained the weakest link in project management. Quoting a report by Swedish International Development Agency, he further says that most stakeholders in the projects studied never saw the findings of evaluations and that the few who did, found nothing very new or useful in them. Quesnel and Quebec (2010) noted that in the last decade, internationally, several billions had been spent on evaluations, yet metaevaluations had shown that a third of evaluations were not worth their investment (in terms of utilization) and another third were of uneven quality.

To improve M\&E result utilization, evaluators have argued for the introduction of Evaluation Capacity Building (ECB) ( Baker \& Bruner, 2006; Díaz-Puente, Yagüe, \& Afonso, 2008; Adams \& Dickinson, 2010). Evaluation Capacity Building (ECB) involves the design and implementation of teaching and learning strategies to help individuals, groups, and organizations, learn about what constitutes effective, useful, and professional evaluation practice. It is strengthening capacities of stakeholders to commission, design, implement, interpret and use evaluations results (Segone, 2008; Preskill \& Boyle, 2008).

Among the areas covered in ECB is professional development in M\&E. Professional development is the process of building knowledge, beliefs, and skills of individuals in monitoring and evaluation. M\&E professional development would include training individuals in skills and techniques that help one to conduct quality evaluations. Training is used to enhance knowledge, skills, and confidence so that project staff are able to conduct adequate evaluations of their own projects (Taylor-Powell \& Boyd; 2008; Huffman, Thomas \& Lawrenz, 2008). Other professionalism development activities considered in this study were suggested by TaylorPowell and Boyd (2008) and they include thematic training, technical 
assistance in M\&E, collaborative evaluation activities, mentoring and coaching and establishing communities of practice enhance professionalism in $M \& E$. Arguably these are activities that facilitate learning that improve knowledge and skills of M\&E practitioners. The question that this study seeks to address is that if these activities were carried out, would they influence $\mathrm{M} \& \mathrm{E}$ result utilization?

\section{Objective of the study}

The study sought to establish the influence of professional development in M\&E on evaluational result utilization. The following hypothesis was formulated; M\&E professional development has significant influence on M\&E results utilization by employees among non-profit organizations in Meru Region of Kenya. To test this, data was collected guided by the following specific objectives;

1. To establish the influence of training in $M \& E$ on $M \& E$ result utilization by project employees in Meru region of Kenya.

2. To assess the influence of technical assistance in M\&E on M\&E result utilization by project employees in Meru region of Kenya.

3. To determine the influence of conducting collaborative evaluation on M\&E result utilization by project employees in Meru region of Kenya.

4. To establish the influence of M\&E Mentoring and coaching programs on $\mathrm{M} \& \mathrm{E}$ result utilization by project employees in Meru region of Kenya.

5. To assess the influence of being a member of M\&E Communities of on $\mathrm{M} \& \mathrm{E}$ result utilization by project employees in Meru region of Kenya.

\section{Literature Review}

Utilization of M\&E result has been a concern of evaluators for some time now. Patton (1997) argued that no matter how rigorous the methods of data collection, design, and reporting are in evaluation, if it does not get used it is a bad evaluation. This concern on M\&E result utilization has resulted to a growing trend toward professionalization in evaluation and as a result, there has been an exponential demand for high quality evaluations (Quesnel et al., 2010) that would be usable in making decisions in project management and policy formulation. According to Taylor-Powell and Boyd (2008), this professionalization is seen in activities aimed at building knowledge, beliefs, and skills of individuals in evaluation. This has been the motivation behind trainings at all levels in M\&E cycle. Since evaluation competence could be determined by factors such as, skills, knowledge, and attitudes of individuals towards $M \& E$, training of individuals to enhance them is key as this offers skills and techniques that one must learn to conduct quality evaluation (Huffman et al., 2008). This need for developing professionalism in M\&E has been necessitated by the fact that only few personnel in project 
management have a background in evaluation as highlighted by TaylorPowell and Boyd(2008). The biggest number of these have an advanced degree in social sciences and may have completed courses in research methods. They argue that these come with their own epistemological and methodological interests and a range of orientations to evaluation that sometimes act against the purposes of evaluations and have influence on the quality of evaluations and their utilization. Therefore there is a need for these personnel to be trained focusing on the right evaluational skills and attitude. The people who carry out M\&E functions are professionals and managers in an organization thus it should be part of the organization's policy to orient and train them for the M\&E functions.

Khan (1998) argued that M\&E function should be looked upon as the collective responsibility in the organization. This means that every person in the organization should have the ability to carry out M\&E. This she says, would help to create a culture of conscious monitoring and evaluation, information sharing, seeking internal assistance in case of problem and most of all sharing credit for success and responsibility for failure. Khan implies that utilization is enhanced in project where project staff has collectively taken time to train and develop their skills in M\&E.

Besides trainings, technical assistance can be used as a means of developing professionalism in M\&E (Taylor-Powell \& Boyd, 2008). It was among activities suggested by Douglah, Boyd and Gundermann (2003) alongside team-building; coaching; mentoring; exchange visits and short and long-term training. The importance of technical expertise in M\&E has been seen consistently over time.

Binnendijk (1989), argued that M\&E operations fail because followup technical assistance and training efforts for project M\&E staff were found to be lacking. The study also found out that technical advisers assigned M\&E responsibilities often lacked evaluation methods skills or pertinent experience and this resulted to massive data collection efforts with no focus, little capacity for data processing and analysis, and even less for presenting findings in a manner that drew management's attention and resulted in actions to improve project performance.

Quoting a study by United Nations Development Programme (UNDP) study, Khan (1998) lists a number of factors that reflect on success and sustainability of M\&E systems. Among them are; Suitable institutional framework with adequate feedback linkage, Staff training and logistics support, Demonstrated benefits of evaluation and Technical assistance. She argues that all of these factors are important and that weakening of any one may threaten the success of the entire system.

$M \& E$ is technical in very many ways. In carrying out evaluations, there is need to do personalized real-time consultation conducted face-to- 
face, by phone, via Web-based technologies, or by e-mail on subject of technical matter in M\&E. This offers moments and opportunities for learning as well as building of relationship that would led to further consultations when the learner perceives the assistance as relevant and practical.

Collaboration in M\&E is seen as an essential component of professional development. It has been noted to be an essential thread in the fabric of M\&E efforts, warranting its explicit inclusion as a key concept in ECB models, efforts, and evaluations (Labin, Duffy, Meyers, Wandersman, \& Lesesne, 2012). These writers found collaborative issues are aspects of existing strengths, strategies, barriers, individual-level outcomes, and organizational-level outcomes. Clinton (2014) argues that collaboration is an important process variable in evaluations. In this study, she uses a number of indicators to show evaluation engagement. Among them are attending evaluation training; resourcing; collaboration in evaluation activities and interest in technical assistance. Collaborations means that these stakeholders were sharing ideas, information, technical advice and actions that would help improve evaluation process and result utilization.

Mentoring and coaching as way of developing professionalism in M\&E has been mentioned in literature. Among the scholars who have mentioned this include Douglah, et al., (2003) and Taylor-Powell and Boyd (2008). Taylor and Boyd argue that mentoring could be seen where an evaluation professional works closely with an interested colleague or colleagues over time, building individual knowledge, skill, and confidence and on the other hand one could be a coach of a program team, bringing evaluation learning to both the program and the coaching teams. In 2008, MERG (Monitoring and Evaluation Reference Group) working with members of the M\&E Capacity-building Technical Working Group (TWG) in a publication, Guidance on Capacity Building for HIV Monitoring and Evaluation, suggested mentoring and coaching as standard capacity building strategies in M\&E.

M\&E community of practice are groups of people brought together by common interest for mutual support and learning in M\&E. This is done by regular interaction between them in an effort to learn how to do something better. According to Taylor-Powell and Boyd (2008), the members in these groups recognize and value the commitment to shared learning and shared practice. These have been formed in various places in the world in recognition of their importance in developing professionalism in M\&E. Examples include Monitoring and Evaluation Community of Practice of Tajikistan (MonEvCoP), The Monitoring and Evaluation Community with members in the Asia and Pacific region and many more

When professional development in M\&E is done, the expected outcomes include the team's ability to conduct and use evaluation results as a 
group and would result to changes in individual knowledge, skills, attitudes, and behaviors. Because individuals have differing needs and orientations, professional development may need to start with a need analysis before any activity is carried out.

\section{Research Methodology}

This study assumed a mixed mode approach to conduct a descriptive survey of the phenomena based on pragmatism philosophical framework for mixed-method approaches in research (Mackenzie \& Knipe, 2006). This approach attempts to consider multiple viewpoints, perspectives, positions, and standpoints of a phenomenon to enable confirmation or corroboration of each other through triangulation and to develop analysis in order to provide richer data (Johnson \& Onwuegbuzie, 2004; Onwuegbuzie \& Leech, 2006; Johnson, Onwuegbuzie \& Turner, 2007).

This study sought to describe and understand professional development in M\&E experience, ideas, practices and the values of the practice in monitoring and evaluation. In this respect, it generated qualitative data. In this approach, knowledge claims are made based primarily on constructivist perspectives (i.e., the multiple meanings of individual experiences socially and historically constructed (Creswell, 2013). The data was collected over a short period of time with an aim of making inferences on the influence of M\&E professional development on M\&E result utilization, thus making the study a cross-sectional survey (Imai \& Nakachi, 1995; Levin, 2006).

This study was based in Meru region of Kenya. The region has two counties, namely Meru Region and Tharaka-Nithi County. The target population was made up of 504 personnel working in nonprofit organizations consisting of project managers, M\&E managers/officers, project officers, data officers and Project implementing staff. These were involved directly in running the projects and were also responsible for carrying monitoring and evaluation activities.

The overall sample size for this study was determined using a formula by Krejcie and Morgan (1970). This method gives a sample size that is more than sufficient to provide enough accuracy to base decisions on the findings with confidence.

$s=\frac{x^{2} N P(1-P)}{d^{2}(N-1)+X^{2} P(1-P)} \mathrm{s}=\frac{(3.84)(504)(0.5)(1-0.5)}{(0.0025)(504-1)+(3.84)(0.5)(1-0.5)} \quad \mathrm{n}=\frac{483.84}{01.2575+0.96} ;$ $\mathrm{n}=218.196 \sim 218$

Using Cohen's (1988) statistical power analysis, the sample required to perform a correlation analysis from a population of 500 is 85 while that which is required to perform a multiple regression analysis is 116 (Cohen, 1992). From this argument Chuan, (2006) argues that for a population of 
about 500, the sampling size can range from a minimum of 85 for performing correlation analysis to a maximum of 217 as recommended by Krejcie and Morgan (1970). Based on this and putting in consideration that this study had a targeted population of 504 with a sample size of 218; there was sufficient room to still conduct analysis with 183 responses.

\section{Sampling Technique}

Stratified random sampling was used to ensures that all parts of a population are represented in the sample in order to increase the efficiency of the study (Kothari, 2009; Kotrlik \& Higgins, 2001). The study used job positions (Project managers, M\&E managers/officers, Project officers, M\&E staff and Project staff) held by the respondents in these organizations as strata. To have proportional representation from each stratum, a sample was drawn independently in the same ratio so as to have similar percentage from each stratum. Random sampling was used to ensure that each element in each stratum had equal probability to be selected for the study.

\section{Research instruments}

This study was based on pragmatism which allows use of various tools in data collection. The mixing rationale of this study at instruments level was guided by two factors; instrument validity; aiming at maximizing the appropriateness and/or utility of the instruments used in the study and significance enhancement to maximize researchers' interpretations of data (Onwuegbuzie \& Leech, 2006). Thus three tools were used in the study, questionnaire being the main tool while face to face interview and document analysis was used to triangulate the findings of the study.

\section{Validity of instruments}

Validity of instruments was ensured by formulating questions to test variables as conceptualized in the literature review and theories studied by a number of researchers in this field (Hogan, Greenfield \&Schmidt, 2001; DeVon et al., 2007). The study then proceeded to seek opinion from experts in $\mathrm{M} \& \mathrm{E}$ to review the appropriate indicators of the variables and verify consistencies of the questionnaire with the content area. These experts were concerned with the relevance (what we judge to be the proper measure); freedom from bias (giving each subject an equal opportunity to score well) and reliability (stable or reproducible) qualities of items in the instruments (Kothari, 2009).

\section{Reliability of instruments}

The study majorly used Likert-type scales, thus it was necessary to calculate and report Cronbach's alpha coefficient for internal consistency 
reliability for all the scales used (Gliem \& Gliem, 2003). Alpha was calculated for each of the concepts to avoid inflating the value of alpha by including larger number of questions (Tavakol \& Dennick 2011). There seems to be general agreement that an alpha coefficient of 0.7 and above is an acceptable reliability coefficient (Nunnaly, 1978; Santos, 1999; Gliem et al., 2003; Tavakol et al., 2011). In this study alpha coefficient for the main variables ranged from 0.730 to 0.897 .

Table 1; Reliability summaries

\begin{tabular}{ccc}
\hline Variable & $\begin{array}{c}\text { Cronbach's } \\
\text { alpha }\end{array}$ & $\begin{array}{c}\text { Number of Items in the } \\
\text { scale }\end{array}$ \\
\hline M\&E result utilization & 0.839 & 5 \\
Training in M\&E & 0.897 & 5 \\
Technical assistance M\&E & 0.837 & 6 \\
Mentoring and coaching programs & 0.740 & 7 \\
Collaborative M\&E & 0.788 & 5 \\
Belonging to M\&E community of practice & 0.730 & 6
\end{tabular}

\section{Data analysis and Discussions}

Descriptive analysis was done to study distributions of variables while inferential analysis was done to do test of significance and hypothesis testing to drawing inferences and conclusions. Correlation analysis was conducted to study variation of two or more variables to determine the amount of correlation between them.

\section{M\&E result utilization}

It was important to establish the extent to which $M \& E$ results were utilized in Meru region. Table 2 shows that the respondents perceived M\&E results as being utilized at high levels in the region since the indicators had means ranging from 4.028 to 4.231 measured using a 5 point likert scale. The use of $M \& E$ data to enhance project sustainability was viewed as the main use of $M \& E$ data in the region with a mean of 4.231 and standard deviation of 0.67434 .

Table 2; Descriptive analysis of M\&E result utilization data

\begin{tabular}{cccc}
\hline & $\mathrm{N}$ & Mean & Std. Deviation \\
\hline $\begin{array}{c}\text { M\&E results enhances project sustainability } \\
\text { M\&E results used in Planning for future } \\
\text { project }\end{array}$ & 182 & 4.231 & .67434 \\
$\quad \begin{array}{c}\text { M } \\
\text { M\&E results used in enhancing project } \\
\text { practices }\end{array}$ & 182 & 4.192 & .71399 \\
$\quad$ & & .088 & .73805 \\
$\begin{array}{c}\text { Use of M\&E results to make project decisions } \\
\text { M\&E results used to learn and establish best } \\
\text { practices (generate knowledge) }\end{array}$ & 183 & 4.071 & .71128 \\
\hline Composite mean & 4.028 & .86957 \\
\hline Source; Primary Data (2015) & \\
\hline
\end{tabular}


The use of M\&E result in Planning for future projects came second with a mean of 4.192 and standard deviation of 0.71399 . This shows that those concerned with planning projects depend to a great extent on the information from $M \& E$ process. Use of $M \& E$ results in decision making came fourth with a mean of 4.071 and standard deviation of 0.71128 . The activity that had the least mean was the use of $M \& E$ result to facilitate learning and establish best practices with a mean of 4.028 and standard deviation of .86957.

The composite mean for $\mathrm{M} \& \mathrm{E}$ result utilization was 4.1038 and a standard deviation of 0.43568 . Measured on a 5 point Likert Scale, this is a high indication that $M \& E$ results are utilized in the region to a great extent.

Interviews were conducted and document reviewed to triangulate the results from the questionnaire and the same trends were observed. Out of the document seen, themes showing utilization of M\&E data were picked out. The use M\&E result in promoting project sustainability, planning future project, making project decisions, enhancing project practices and learning from M\&E. Project sustainability was more frequent showing that the organizations were using $\mathrm{M} \& \mathrm{E}$ result more to determine sustainability of their projects.

The concept of sustainability was a major concern for almost all project stakeholders, as ten of those interviewed also agreed that they have to handle issues that may threaten project sustainability as a matter of priority. As one manager said, "M\&E information indicating high levels of community participation is an indicator of ownership of the project, meaning we expect higher chances of sustainability in these projects."

Those interviewed confirmed that they are able to design better projects on the basis of past practices. The documents reviewed indicated that a number of project officers made reference to M\&E reports in planning for projects and making daily decisions. This being one area where M\&E information needs to be used more regularly in comparison to other areas studied, it was noted that there is need to improve. Most of the respondents interviewed said that utilization would improve if communication of M\&E result would be done in a better way so that information needed would be available when these decisions are taken. As one M\&E manager indicated, "in most cases, M\&E results are delayed thus most decisions are made using the raw data."

The use of $M \& E$ results to enhance project practices scored a mean of 4.088 and standard deviation of 0.73805 . From the interviews, a project manager said that, "M\&E activities are designed to be undertaken by all employees of the organizations in as far as collecting data is concerned. The employees are encouraged to make use of the data collected to make adjustments to project activities on their own and inform the management." 
As the information is passed on to the manager, employees have already used it to improve their performance.

Practices in project management that are normally noted to yield better results than others in terms of their performance are distinguished by use of $M \& E$ tools. After they are distinguished, the employees, are impressed upon to use them. Another manager said that 'employees may not associate change in project practice to $M \& E$ because sometimes the managers do not give reasons why these changes were taken and neither do they attribute them to M\&E results."

\section{Professional Development in $\mathrm{M} \& \mathrm{E}$}

A descriptive analysis of various indicators of M\&E professional development (as a variable of ECB) occurring among non-organizations in Meru Region was done. The factors singled out as indicators of $\mathrm{M} \& \mathrm{E}$ professional development in this study were; training and/or workshop on $\mathrm{M} \& \mathrm{E}, \mathrm{M} \& \mathrm{E}$ technical assistance in $\mathrm{M} \& \mathrm{E}$, collaborative evaluation, $\mathrm{M} \& \mathrm{E}$ mentoring and coaching programs and seeking membership/belonging to M\&E communities of practice.

Table 3; Descriptive statistics professional development activities in M\&E

\begin{tabular}{cccc}
\hline Description & $\mathrm{N}$ & Mean & Std. Deviation \\
\hline Receives M\&E technical assistance in M\&E & 183 & 3.1421 & .92078 \\
Training and/or workshop on M\&E & 183 & 2.8798 & .82992 \\
M\&E mentoring and coaching programs & 182 & 2.6044 & 1.24713 \\
Collaborative M\&E with other people or & 183 & 2.3279 & 1.17746 \\
organizations & & & \\
Memberships to M\&E community of Practice & 182 & 2.1484 & 1.22360 \\
\hline Composite mean & 183 & 2.6153 & .65414 \\
\hline
\end{tabular}

Source; Primary Data (2015)

From Table 4, receiving M\&E technical assistance in $M \& E$ was the most popular activity among organizations in the region with a mean of 3.1421 and standard deviation of 0.92078. From the interviews, it was evident that the levels of technical assistance received was low since it was done mostly on the basics such as use of computer software in M\&E, reporting and dissemination rather than technical help in issues such as M\&E tool development, indicator identification and measurements or determining appropriate methodology for an evaluation in line with M\&E purpose. Only three managers reported that they had training on methodology and indicator development among the ten interviewed. More importantly, the development of M\&E purpose and objectives that are the premise of M\&E result utilization was done only by four organizations among those interviewed.

Training and/or attending workshop on M\&E was done to a moderate extent with a mean of 2.8798 and standard deviation of 0.82992. Evidence from documents reviewed from these organizations indicated that the 
organizations had done a number of training and others were planned to be done. From the interviews, it was indicated that, trainings have been done mostly on use of tools that were already developed, reporting and presentation of data. It was evident that little had been done on equipping the personnel with skills to conceptualize M\&E, interpret M\&E reports and making sense of M\&E data. However, experience of these employees should be put into account.

M\&E mentoring and coaching programs had a Mean of 2.6044 and standard deviation of 1.24713. From the interviews, it was evident that a number of organizations didn't have programs in place to induct their employees into M\&E culture of the organization but they expected these employees to perform M\&E functions. They relied on individual employees seeking assistance from other. However, in a number of others it was a known requirement that a supervisor was responsible for the induction. There was no evidence from the document review that gave record of this activity being done. However, from the interviews, it emerged that in a number of organizations, this activity is alluded to in human resource manual as part of a supervisor's responsibility.

The activity of carrying out collaborative M\&E with other people or organizations was among the least performed in the region with a mean of 2.3279 (done to a little extent) and a standard deviation of 1.17746, showing a wide variation in the scores. This was evident even from document reviewed which show that only three organizations had recorded this kind of an activity. It was also established from interviews that even those doing similar projects, and have common funders are doing this to a small extent and the collaborative M\&E aspect is normally initiated by the donors. Other inter- organizational collaborations in M\&E activities had not been seen in the region though there was evidence of organizations borrowing and using tools developed by others especially in agricultural projects that use beneficiaries as the main agents of collecting data from the field.

The least done activity among activities that promote professional development in M\&E was belonging to or seeking memberships to M\&E community of Practice with a mean of 2.1484 and a standard deviation of 1.2236. Only a few respondents mostly from the management belonged to or have sought to belong to these communities of practice. Only three of the ten interviewed were active members of these communities.

The composite mean for the ECB activity of professional development was 2.6153 and standard deviation of 0.65414 . This means that the activity is performed to a moderate extent (1.8 and 2.6) measured on a 5 point likert scale. This means that organizations have not taken professional development very seriously as a means of improving M\&E processes. 
However this was a significant attempt in the implementation of these activities.

\section{Correlation analysis of the variables}

Correlation analysis was done to explore the direction of the relationships between independent variable and dependent variable. Having measured these variables on a likert scale, Pearson product moment correlation was used and these relationships were determined at a confidence level of $95 \%$ meaning that the sample proportion (p) was less than or equal to 0.05 . Table 5 shows the correlation coefficients of independent variables on dependent variables.

The relationship between training in $M \& E$ and $M \& E$ result utilization was a moderate positive correlation where $[\mathrm{r}=.455, \mathrm{n}=183$, $\mathrm{p}=.0005<.05]$, while the relationship between technical assistance in M\&E and $M \& E$ result utilization was established as [ $\mathrm{r}=.313, \mathrm{n}=183, \mathrm{p}=.0005<.05$ ] which was also a moderate positive relationship. The relationship between carrying collaborative $M \& E$ and $M \& E$ result utilization was $[r=.245, n=183$, $\mathrm{p}=.0005<.05]$, while that of having mentoring and coaching programs in M\&E was moderate with $[\mathrm{r}=.432, \mathrm{n}=182, \mathrm{p}=.0005<.05]$, there was a moderate, positive correlation between belonging to an M\&E community of practice and $M \& E$ result utilization with $[\mathrm{r}=.472, \mathrm{n}=182, \mathrm{p}=.0005<.05]$.

Overall there was a strong, positive correlation between Professional development in $M \& E$ and $M \& E$ result utilization with $[r=.639, n=183$, $\mathrm{p}=.0005<.05]$. 


\begin{tabular}{|c|c|c|c|c|c|c|c|}
\hline & & & $\begin{array}{l}\text { Trainin } \\
\text { g on } \\
\text { M\&E }\end{array}$ & $\begin{array}{c}\text { Techni } \\
\text { cal } \\
\text { assista } \\
\text { nce in } \\
\text { M\&E } \\
\end{array}$ & $\begin{array}{c}\text { Collaborative } \\
\text { M\&E }\end{array}$ & $\begin{array}{c}\text { M\&E } \\
\text { mentoring } \\
\text { and } \\
\text { coaching } \\
\text { programs }\end{array}$ & $\begin{array}{l}\text { Membership } \\
\text { s to M\&E } \\
\text { community } \\
\text { of Practice }\end{array}$ \\
\hline \multirow{23}{*}{$\begin{array}{l}\text { Spear } \\
\text { man's } \\
\text { rho }\end{array}$} & Training on & Correlation & 1.000 & & & & \\
\hline & M\&E & Coefficient & & & & & \\
\hline & & Sig. (2-tailed) & . & & & & \\
\hline & & $\mathrm{N}$ & 183 & & & & \\
\hline & Technical & Correlation & $.334^{* *}$ & 1.000 & & & \\
\hline & assistance in & Coefficient & & & & & \\
\hline & M\&E & Sig. (2-tailed) & .000 & & & & \\
\hline & & $\mathrm{N}$ & 183 & 183 & & & \\
\hline & Collaborative & Correlation & .140 & .063 & 1.000 & & \\
\hline & M\&E & Coefficient & & & & & \\
\hline & & Sig. (2-tailed) & .059 & .397 & & & \\
\hline & & $\mathrm{N}$ & 183 & 183 & 183 & & \\
\hline & M\&E & Correlation & $.395^{* *}$ & $.249^{* *}$ & .091 & 1.000 & \\
\hline & mentoring & Coefficient & & & & & \\
\hline & and coaching & Sig. (2-tailed) & .000 & .001 & .221 & . & \\
\hline & programs & $\mathrm{N}$ & 182 & 182 & 182 & 182 & \\
\hline & $\begin{array}{l}\text { Memberships } \\
\text { to M\&E }\end{array}$ & $\begin{array}{l}\text { Correlation } \\
\text { Coefficient }\end{array}$ & $.188^{*}$ & $.201^{* *}$ & .114 & $.386^{* *}$ & 1.000 \\
\hline & community of & Sig. (2-tailed) & .011 & .006 & .125 & .000 &. \\
\hline & Practice & $\mathrm{N}$ & 182 & 182 & 182 & 181 & 182 \\
\hline & M\&E Result & Correlation & $.455^{* *}$ & $.313^{* *}$ & $.245^{* *}$ & $.432^{* *}$ & $.472^{* *}$ \\
\hline & utilization & Coefficient & & & & & \\
\hline & & Sig. (2-tailed) & .000 & .000 & .001 & .000 & .000 \\
\hline & & $\mathrm{N}$ & 183 & 183 & 183 & 182 & 182 \\
\hline
\end{tabular}

\section{Test of hypothesis}

The hypothesis was tested to establish the statistical significance of the influence of the respective independent variables on the dependent variable. In using $\mathrm{F}$ test to determine significance, the general rule is if $\mathrm{F}_{\text {calculated }}<\mathrm{F}_{\text {critical, }}$ you should accept the null hypothesis because then $\mathrm{p}>.05$ and when $F_{\text {calculated }}>F_{\text {critical }}$, you should reject the null hypothesis because $\mathrm{p}<.05$. In other words if $\mathrm{p}$-value $<\alpha$, reject the null hypothesis and accept alternative hypothesis and if p-value $>\alpha$, accept the null hypothesis and reject the alternative hypothesis (Feir-Walsh and Toothaker (1974); Erdfelder, Faul, and Buchner, (1996); Huitema, (2011).

It is important to note that the model in this test focus on determining the contribution of the variables being measured to the dependent variable and not the goodness of the model in explaining the phenomenon in totality. This therefore means that the coefficient of determination can go lower than 0.7 thresholds that qualify regression models as sufficiently explaining the phenomenon statistically. The hypothesis; M\&E professional development has significant influence on M\&E results utilization by employees among non-profit organizations in Meru Region was tested. A composite index for M\&E result utilization was used as the dependent variable. The test was based on a linear regression model; $y=a+\beta_{1} X_{1}+e$ where 


$$
\begin{aligned}
& y=M \& E \text { result utilization } \\
& a=\text { constant } \\
& \beta_{1}=\text { Beta coefficient } \\
& X_{1}=\text { M\&E professional development } \\
& e=\text { error term }
\end{aligned}
$$

The results are presented in Table 4 . The model summary show the correlation (r) and the coefficient of determination (R-square), where $r=$ 0.639 meaning that $\mathrm{M} \& \mathrm{E}$ professional development activities have a relatively strong influence on $\mathrm{M} \& \mathrm{E}$ result utilization at $\mathrm{P}=0.0005<0.05$. The value of $\mathrm{R}$ squared (0.408) suggest that $\mathrm{M} \& \mathrm{E}$ professional development activities explain $40.8 \%$ of the variation in M\&E result utilization. This means that $59.2 \%$ of $\mathrm{M} \& \mathrm{E}$ result utilization is explained by other factors not in the model. The Durbin-Watson statistic was 1.778, which is less than 2.0 but close enough, showing absence of autocorrelation and that the regression analysis had not violated the assumptions of correlation.

Table 4; Regression result of the influence of professional development in M\&E on M\&E result utilization

\begin{tabular}{cccccc}
\hline Model summaries & $\mathrm{R}$ & R-Square & $\begin{array}{c}\text { Durbin- } \\
\text { Watson }\end{array}$ & $\begin{array}{c}\text { Unstandardized } \\
\text { coefficient } \\
\text { Std. Error }\end{array}$ \\
\hline $\begin{array}{c}\text { (Constant) } \\
\text { Professional Development } \\
\text { Activities. }\end{array}$ & .639 & .408 & 1.778 & & \\
\hline & & & & 2.657 & .105 \\
& & & .436 & .039 \\
\hline
\end{tabular}

a. Dependent Variable: M\&E Result utilization

b. Predictors: Professional Development Activities.

Source; Primary Data (2015)

The $\mathrm{F}$ ratio was significant as $\mathrm{F}(1,181)=124.688, \mathrm{P}=0.0005<0.05$. This means that professional development has a strong and positive influence on M\&E result utilization. Therefore from the result of the test above we reject the null hypothesis and accept the alternate hypothesis which means that M\&E professional development has significant influence on M\&E results utilization by employees among non-profit organizations in Meru Region. To substitute the values from this model, $\mathrm{Y}=2.657+0.436 \mathrm{X}_{1}+\mathbf{e}$. This implies that for every unit increase in professional development there is an increase of $43.6 \%$ in $M \& E$ result utilization.

The result of this study revealed that organizations are learning from M\&E against the background of studies that had revealed otherwise in other areas. A study conducted by Taut (2007) showed that there was low organizational readiness for learning from evaluation due to lack of role model leadership, defective communication, lack of transparency and lack of formal structures and processes to encourage reflection. The only areas that 
the respondents felt needed improvement among the reasons cited by Taut (2007) were communication and conflicts within the internal organs of the organizations.

A number of organizations were implementing projects without baseline surveys and others know that such surveys exist but they have never seen them. This is among the reasons advanced to explain why M\&E fail according to Guijt (1999). In most cases, studies have revealed why stakeholders have failed to make use of M\&E result. Some of these reasons include, lack of flexibility and responsiveness to the information needs of key stakeholders; lack of a strong methodology that is appropriate in the context of every evaluation, failure to make evaluations simple and inexpensive, not making demands on already overtaxed program staff; building Communication channels to ensure that clients are kept informed and so on (Koppel, 1986; Mierlo, Arkesteijn, \& Leeuwis, 2010b; Seasons, 2003; Tilbury, 2007; Tilbury 2009). In their arguments, M\&E results utilization need to be emphasized in projects organizations since it was low. However, this study recorded moderately high levels of M\&E result utilization in the region.

From the above argument, there is need to carry out a study to seek answers to the factors that may have led to this high perception on M\&E result utilization in the area and if the factors advanced in the literature cited above are in play in the region and if not or how they have controlled them to enable this apparent high level of M\&E result utilization.

The findings of this study agree with Hueftle et al. (2002) who argued that professional development activities of ECB are designed to continuously create and sustain overall organizational processes that lead to quality evaluation and its routine use. With a composite mean of 2.6153, the organizations in the region could be said to be developing professionalism in $\mathrm{M} \& \mathrm{E}$ to a moderate extent, which correlate to M\&E result utilization at [ $\mathrm{r}$ $=.639, \mathrm{n}=183, \mathrm{p}=.0005<.05]$. This is a high correlation which means that with more training, there would be an increase of M\&E result utilization.

The results also agree with one of the aims of ECB activities as advanced by Taylor-Powell et al., (2008) who indicated that professional development in $\mathrm{M} \& \mathrm{E}$ increases the use of evaluation results as well as increasing generation of knowledge through evaluations information. Knowledge generation as an indicator had a mean of 4.028 which means that the organizations used $\mathrm{M} \& \mathrm{E}$ result as a learning tool to a great extent.

The findings also validate the arguments in a report by IFAD, (2002) that suggested that professional development activities have a role in strengthening of organizational evaluation approaches, developing mechanisms and establishing systems and processes for identifying, collecting, and using evaluative information. This was also alluded to by 
Haffman et al., (2008) who said that professional development in M\&E offers skills and techniques that one must learn to conduct and use evaluations.

As was seen in the results of this study, professional development in M\&E strengthens the capacity of clients and stakeholders to interpret and use the findings of the evaluation in the region. This view was also advanced by Naccarella et al. (2007). This shows that there is need for organizations to build capacity for all the stakeholders not only project staff directly involved in $M \& E$ as long as these stakeholders are interested the project, there is need to show them how to understand the progress by actively involving them in the processes of evaluation.

Quesnel et al., (2010) pointed out that, as the demand for quality usable evaluations increases, there is need to develop professionalism in M\&E to meet that demand. Evidently, it was determined in this study that professional development in M\&E contributes greatly to utilization of $\mathrm{M} \& \mathrm{E}$ results. Not only do professional development activities equip the general stakeholders on skills to carry out M\&E activities, but as Khan (1998) put it, M\&E utilization is enhanced in project where project staffs have taken time to develop their skills in M\&E.

Therefore M\&E professional development is seen to be responsible to a great extent for growth in evaluation competence as determined by factors such as, skills, knowledge, attitudes of individuals towards M\&E and ability to use evaluation result (Huffman et al., 2008).

\section{Conclusion}

There was a high level of utilization of M\&E resources in the region but this study was limited only to the utilization at project level. It was established that there is little sharing among project organizations of M\&E result and thus hinders utilization across different projects/programs. The issue of communicating these results was therefore an area of concern in the region.

The activities studied as indicators of M\&E professional development were: training and/or attending workshops in M\&E, technical assistance in M\&E, collaborative evaluation, $M \& E$ mentorship and coaching programs and seeking membership to M\&E communities of practice. The composite mean was 2.6153 and standard deviation of .65414, meaning that the activities were done to a moderate extent. However, a unit increase in professional development explained $40.8 \%$ of the variation in respondents' score in M\&E result utilization scale. This implies that organizations should pay close attention to activities that develop professionalism in M\&E as it has a direct influence of utilization of this result which is the justification for the total cost of $M \& E$. 
These results are validated by the regression equation in which it was empirically demonstrated that for every unit increase in professional development there is an increase of $43.6 \%$ in $M \& E$ result utilization.

\section{References:}

Adams, J., \& Dickinson, P. (2010). Evaluation Training to Build Capability in the Community and Public Health Workforce. American Journal of Evaluation, 31(3), 421-433. doi:10.1177/1098214010366586

Baker, A., \& Bruner, B. (2006). Evaluation capacity and evaluative thinking in organizations (Vol. 60). Cambridge, MA: Bruner Foundation Inc.

Binnendijk, A. L. (1989). Donor agency experience with the monitoring and evaluation of development projects. Evaluation Review, 13(3), 206-222.

Chuan, L.C., (2006). Sample size estimation using Krejcie and Morgan and Cohen statistical power analysis: a comparison. Jurnal Penyelidikan IPBL, Jilid 7, 2006

Clinton, J. (2014). The True Impact of Evaluation Motivation for ECB. American Journal of Evaluation, 35(1), 120-127.

Cohen, J. (1988). Statistical power analysis for the behavioral sciences. Second Edition. Hillsdale, NJ: Lawrence Erlbaum Associates, Publishers.

Cohen, J. (1992). Quantitative methods in psychology: A power primer. Psychological Bulletin, 112(1), 155-159.

Creswell, J. W. (2013). Research design: Qualitative, quantitative, and mixed methods approaches. Sage Publications, Incorporated.

DeVon, H. A., Block, M. E., Moyle-Wright, P., Ernst, D. M., Hayden, S. J., Lazzara, D., Kostas-Polston, E. (2007). A psychometric toolbox for testing validity and reliability. Journal of Nursing Scholarship, 39(2), 155-164.

Díaz-Puente, J. M., Yagüe, J. L., \& Afonso, A. (2008). Building Evaluation Capacity in Spain A Case Study of Rural Development and Empowerment in the European Union. Evaluation Review, 32(5), 478-506. doi:10.1177/0193841X08319015 dmechapter10.pdf. (n.d.). Retrieved June 10, 2014, from http://www.sfcg.org/Documents/dmechapter10.pdf

Douglah, M., Boyd, H., \& Gundermann, D. (2003). Nurturing the development of an evaluation culture in public educational agencies. In Annual Conference of the American Evaluation Association, Reno NV.

Gliem, J. A., \& Gliem, R. R. (2003). Calculating, interpreting, and reporting Cronbach's alpha reliability coefficient for Likert-type scales. Midwest Research-to-Practice Conference in Adult, Continuing, and Community Education. Retrieved from https://scholarworks.iupui.edu/handle/1805/344 Guijt, I. (1999). Participatory Monitoring \& Evaluation for Natural Resources Management and Research. Socio-economic Methodologies for Natural Resources Research. Natural Research Institute 
Hogan, S. Daryl B. Greenfield, Lee A. Schmidt, N. (2001). Development and Validation of the Hogan Grief Reaction Checklist. Death Studies, 25(1), 132. doi:10.1080/07481180125831

Huffman, D., Thomas, K., \& Lawrenz, F. (2008). A Collaborative Immersion Approach to Evaluation Capacity Building. American Journal of Evaluation, 29(3), 358-368. doi:10.1177/1098214008318798

IFAD, (2002). Managing for Impact in Rural Development; A Guide for Project M\&E. IFAD. Rome.

Imai, K., \& Nakachi, K. (1995). Cross sectional study of effects of drinking green tea on cardiovascular and liver diseases. Bmj, 310(6981), 693-696.

Johnson, R. B., \& Onwuegbuzie, A. J. (2004). Mixed methods research: A research paradigm whose time has come. Educational Researcher, 33(7), 14-26.

Johnson, R. B., Onwuegbuzie, A. J., \& Turner, L. A. (2007). Toward a definition of mixed methods research. Journal of Mixed Methods Research, 1(2), 112-133.

Khan, M. A. (1998). Evaluation Capacity Building An Overview of Current Status, Issues and Options. Evaluation, 4(3), 310-328. doi:10.1177/13563899822208626

Koppel, B. (1986). Benefit Monitoring and Evaluation Systems in Development Projects: Notes from Asia. Impact Assessment, 5(1), 9-24. doi:10.1080/07349165.1986.9725567

Kothari, C. R. (2009). Research methodology: methods and techniques. New Age International. Retrieved from http://books.google.com/books?hl=en\&lr=\&id=8c6gkbKi4C\&oi=fnd\&pg=PR7\&dq=research+methodology,+methods

Kotrlik, J. W. K. J. W., \& Higgins, C. C. H. C. C. (2001). Organizational research: Determining appropriate sample size in survey research appropriate sample size in survey research. Information Technology, Learning, and Performance Journal, 19(1), 43.

Krejcie, R.V. \& Morgan, D.W. (1970) Determining sample size for research activities. Educational and Psychological Measurements, 30, 607-610.

Labin, S. N., Duffy, J. L., Meyers, D. C., Wandersman, A., \& Lesesne, C. A. (2012). A research synthesis of the evaluation capacity building literature. American Journal of Evaluation, 1098214011434608.

Levin, K. A. (2006). Study design III: Cross-sectional studies. EvidenceBased Dentistry, 7(1), 24-25. doi:10.1038/sj.ebd.6400375

Mackenzie, N., \& Knipe, S. (2006). Research dilemmas: Paradigms, methods and methodology. Issues in Educational Research, 16(2), 193-205.

Mierlo, B. van, Arkesteijn, M., \& Leeuwis, C. (2010a). Enhancing the Reflexivity of System Innovation Projects With System Analyses. American Journal of Evaluation, 31(2), 143-161. doi:10.1177/1098214010366046 
UNAIDS. (2008) Guidance on Capacity Building for HIV Monitoring and Evaluation. Geneva UNAIDS.

Naccarella, L., Pirkis, J., Kohn, F., Morley, B., Burgess, P., \& Blashki, G. (2007). Building evaluation capacity: definitional and practical implications from an Australian case study. Evaluation and Program Planning, 30(3), 231-236. doi:10.1016/j.evalprogplan.2007.05.001

Nunnaly, J. (1978). Psychometric theory. New York: McGraw-Hill.

Patton, M. Q. (1997). Utilization-focused evaluation: The new century text.

Sage.

Retrieved

from

http://books.google.com/books?hl=en\&lr=\&id=1Fvo0jeD0mgC\&oi=fnd\&pg

=PR13\&dq=Patton,+M.Q.+1997.+Utilization-focused+Evaluation:

Patton, M. Q. (1999). Utilization-focused evaluation in Africa. In Training sessions at the Inaugural Meeting of the African Evaluation Association in Nairobi, Kenya, September. Retrieved from http://www.fivehokies.com/Evaluation/Evaluation\%20Approaches/Participa nt\%Oriented/Utilization-Focused\%20Evalaution\%20Textbook\%20-

\%20Quinn-Patton.pdf

Preskill, H., \& Boyle, S. (2008). A Multidisciplinary Model of Evaluation Capacity Building. American Journal of Evaluation, 29(4), 443-459. doi:10.1177/1098214008324182

Quesnel, J. S., Senior Facilitator, U., \& Québec, E. (2010). The Professionalization of Evaluation. From Policies to Results, 164.

Santos, J. R. A. (1999). Cronbach's alpha: A tool for assessing the reliability of scales. Journal of Extension, 37(2), 1-5.

Seasons, M. (2003). Monitoring and Evaluation in Municipal Planning: Considering the Realities. Journal of the American Planning Association, 69(4), 430-440. doi:10.1080/01944360308976329

Segone, M. (2008). Bridging the gap. The role of monitoring and evaluation in evidence-based policy making. Retrieved from http://www.popline.org/node/210066_Tavakol, M., \& Dennick, R. (2011). Making sense of Cronbach's alpha. International Journal of Medical Education, 2, 53-55.

Taylor-Powell, E., \& Boyd, H. H. (2008). Evaluation Capacity Building in Complex Organizations. New Directions for Evaluation. Retrieved from http://www.eric.ed.gov/ERICWebPortal/detail?accno=EJ824994

Thomas, D. R. (2006). A general inductive approach for analyzing qualitative evaluation data. American Journal of Evaluation, 27(2), 237-246. Tilbury, D. (2007). Monitoring and Evaluation during the UN Decade of Education for Sustainable Development. Journal of Education for Sustainable Development, 1(2), 239-254. doi:10.1177/097340820700100214 
Tilbury, D. (2009). Tracking Our Progress A Global Monitoring and Evaluation Framework for the UN DESD. Journal of Education for Sustainable Development, 3(2), 189-193. doi:10.1177/097340820900300215 Woodhill, J. (2005). M\&E as learning: Rethinking the dominant paradigm. Monitoring and Evaluation of Soil Conservation and Watershed Development Projects. Retrieved from http://www.capfida.mg/km/atelier/wageningen/download 